\title{
Farklı yöntemlerle konsantre edilen kefirlerin fizokokimyasal ve mikrobiyolojik bazı özelliklerinin belirlenmesi
}

\section{Determination of some physicochemical and microbiological properties of kefir concentrated by different methods}

\author{
Muammer DEMIR@, Demet ÖZKISA(i) \\ Akdeniz Üniversitesi, Mühendislik Fakültesi, Gıda Mühendisliği Bölümü, 07058, Antalya \\ Sorumlu yazar (Corresponding author): M. Demir, e-posta (e-mail): mdemir@akdeniz.edu.tr \\ Yazar(lar) e-posta (Author e-mail): demetozkisa@hotmail.com
}

\section{MAKALE BILGİSİ}

Alınış tarihi 02 Mart 2020

Düzeltilme tarihi 29 Haziran 2020

Kabul tarihi 09 Temmuz 2020

\section{Anahtar Kelimeler:}

Konsantre kefir

Kefir kültürü

Kefir danesi

Evaporasyon

\begin{abstract}
ÖZ
Yapılan bu çalışmada farklı yöntemlerle konsantre edilen kefirlerin depolama süresine bağl olarak bazı fizikokimyasal ve mikrobiyolojik özellikleri belirlenmiştir. Bu amaçla starter kültür ve kefir danesinden, her ikisinden de ayrı ayrı olmak üzere; sütlere süt tozu ilave edilmesi, üretilen kefirlerin süzülmesi, üretimlerde kullanılan sütlerin evapore edilmesi ve üretilen kefirlerin evapore edilmesi seklinde dört farklı yöntemle elde edilen toplam sekiz farklı konsantre kefir, $4^{\circ} \mathrm{C}$ 'de 30 gün süreyle depolanmıştır. Depolamanın 1., 15. ve 30 . günlerinde; örneklerde titrasyon asitliği, $\mathrm{pH}$, tekstür, su tutma kapasitesi ve mikrobiyolojik analizler yapılmıștır. Çalışma sonucunda konsantre kefir örneklerinin titrasyon asitliği ve sertlik değerlerinin depolama süresince arttığı, $\mathrm{pH}$ değerlerinin ise azaldığı belirlenmiştir. Konsantre kefir örneklerinde gerçeklestirilen mikrobiyolojik analizler sonucunda, laktobasil, laktokok, lökonostok ve asetik asit bakterilerinin sayılarında depolama süresince azalma gözlenirken, maya sayılarında ise artı̧ görülmüştür. Depolama süresince konsantre kefir örneklerinin su tutma kapasitesine ait değerler arasında istatistiksel bir farklılık $(P<0.05)$ olduğu, depolamanın birinci gününde elde edilen su tutma kapasitesi değerlerinin daha düşük olduğu bulunmuștur. Yapılan bu çalıșmada, ülkemizin probiyotik ürün yelpazesine farklı tat ve aromaya sahip yeni bir ürün kazandırılması, konsantrasyon işlemi ile ürünlerin ihtiva ettiği probiyotik mikroorganizma sayısının dolaylı olarak artırılması ve raf ömrü boyunca kritik sayının altına düşmesinin engellenmesi, ürünün raf ömrünün uzatılması ile taşıma ve depolama maliyetlerinin azaltılması amaçlanmıştır.
\end{abstract}

\section{ARTICLE INFO}

Received 02 March 2020

Received in revised form 29 June 2020

Accepted 09 July 2020

\section{Keywords:}

Concentrated kefir

Kefir culture

Kefir grain

Evaporation

\begin{abstract}
In this study, some physicochemical and microbiological properties of kefirs concentrated by different methods were determined depending on storage period. For this purpose, from the starter culture and kefir grain, both separately; Eight different concentrate kefir obtained by four different methods such as adding milk powder to the milk, filtering the produced kefir, evaporating the milk used in the productions and evaporating the produced kefir were stored for 30 days at $4^{\circ} \mathrm{C}$. On the $1^{\text {st }}, 15^{\text {th }}$ and $30^{\text {th }}$ days of storage; titration acidity, $\mathrm{pH}$, texture, water holding capacity and microbiological analyzes were performed in the samples. At the end of the study, it was determined that titration acidity and hardness values of concentrated kefir samples increased during storage and $\mathrm{pH}$ values decreased. As a result of microbiological analysis carried out in concentrated kefir samples, throughout the storage period the number of lactobacilli, lactococcus, leukonostoc and acetic acid bacteria decreased, while the number of yeasts increased. It was found that there was a statistical difference $(P<0.05)$ between the values of water holding capacity of concentrated kefir samples during storage, and the water holding capacity values obtained on the first day of storage were lower. The aim of this study is to add a new product with different taste and aroma to the probiotic product range of our country. By the indirectly increasing the number of probiotic microorganisms contained in the products by concentration process, it was prevented falling below the critical number during the shelf life. By the concentration process, it was provided extending the shelf life of the product and reducing transportation and storage costs.
\end{abstract}




\section{Giriş}

Türk Gıda Kodeksine göre fermente süt ürünü; sütün uygun mikroorganizmalar tarafindan fermentasyonu ile $\mathrm{pH}$ değerinin koagülasyona yol açacak veya açmayacak şekilde düşürülmesi sonucu oluşan ve içermesi gereken mikroorganizmaları yeterli sayıda, canlı ve aktif olarak bulunduran süt ürünü olarak tanımlanmaktadır (Türk Gıda Kodeksi-Fermente Süt Ürünleri Tebliği 2009). Temel fonksiyonu, elde edilen ürün ile dolaylı olarak sütün raf ömrünü uzatmak olan fermentasyon, bu sayede sütün sindirimini kolaylaştırmakta, çeşitli tat ve aromaya sahip yeni süt ürünlerinin elde edilmesini sağlamaktadır (Surono ve Hosono 2011). Fermente süt ürünlerinin, soğutma teknolojilerinin olmadığı eski çağlarda oda sıcaklığında bekletilen sütlerde, laktik asit ve diğer bakterilerin gelişmesi sonucu ortaya çıktığı varsayılmaktadır. Böylelikle mikroorganizma aktivitesi sonucu hoş bir tat kazanmış ve yüksek asit içeriğinden dolayı da raf ömrü uzamış ürünler elde edilmiştir. Raf ömrünün uzun olması, fermente süt ürünlerini cazip kılmıştır. İlk olarak Orta Doğu'da ortaya çıktığına inanılan fermente süt ürünleri, zamanla dünyanın dört bir tarafına yayılmıştır (Mistry 2001).

Probiyotik içeren gıdalar, yani yoğurt, peynir, kefir gibi fermente süt ürünleri, besin değerlerinin yanında, hastalık önleyici ve bağışıklık sistemini güçlendirici özellikleri olan fonksiyonel gıdalardır. Canlı mikroorganizma olarak tanımlanan probiyotiklerin, sağlığa faydalı etkilerini gösterebilmeleri için midedeki hidroklorik asite dayanıklı olup, sindirim sistemini geçerek bağırsaklara canlı bir şekilde ulaşabilmeleri gerekir. Lactobacillus ve Bifidobacterium türleri, insan tüketimi için uygun probiyotik bakterilerdir (Abdelrahman ve ark. 2010).

Probiyotik fermente süt ürünü olan kefir, Türk Gıda Kodeksi'ne göre "Fermentasyonda spesifik olarak Lactobacillus kefiri, Leuconostoc, Lactococcus ve Acetobacter cinslerinin değişik suşları ile laktozu fermente eden (Kluyveromyces marxianus) ve etmeyen mayaları (Saccharomyces unisporus, Saccharomyces cerevisiae ve Saccharomyces exiguus) içeren starter kültürler ya da kefir danelerinin kullanıldığı fermente süt ürünü” olarak tanımlanmaktadır (Türk Gıda Kodeksi-Fermente Süt Ürünleri Tebliği 2009).

Kefir, içerdiği bakteri ve mayalardan dolayı doğal probiyotik özellik gösterir ve fonksiyonel bir fermente süt ürünüdür. Sağlık açısından faydalı bir içecek olan kefir, gastrointestinal sistemi geliştirir, bağışıklık sistemini güçlendirir, laktoz toleransını arttırır, kolesterol düşürücü ve kanser önleyici özelliği vardır (Güzel-Seydim ve ark. 2011). Ayrıca kefir, vücudun temel fonksiyonları ve çeşitli faaliyetleri için gerekli olan mineraller ve elzem aminoasitler bakımından zengindir. Kefirde bol miktarda bulunan triptofan elzem aminoasitinin ve kalsiyum, magnezyum mineral maddelerinin, sinir sistemi üzerinde rahatlatıcı bir etkisi olduğu bilinmektedir. Yeterli miktarda alınması durumunda; böbrek, karaciğer, sinir sistemine ve deri hastalıklarına sayısız fayda sağladığı bilinen $\mathrm{B}_{12}, \mathrm{~B}_{1}, \mathrm{~K}$ vitaminleri de kefirde bulunmaktadır (Korkut 2010).

Konsantre süt, su oranı azaltılmış ve dolayısıyla raf ömrü arttırılmış süt demektir. Sütün su oranı, vakumda buharlaştırma, santrifüjleme, ekstraksiyon, liyofilizasyon ve membran filtrasyonu yöntemleriyle azaltılabilir. Sütü konsantre etmek için en çok kullanılan yöntemler membran filtrasyonu ve vakumda buharlaştırmadır. Sütü konsantre etmek, üreticiye, işletmeciye ve tüketiciye; ekonomik, taşıma ücreti azaltılmış, işlevsel ürün sunar (Farkye ve Rehman 2011). Özellikle raf ömrünü uzatmak için konsantre edilen fermente süt ürünleri,
Türk Gıda Kodeksi'ne göre; protein oranı fermentasyondan önce veya sonra en az \%5.6 oranına yükseltilmiş süzme yoğurt veya torba yoğurdu, kış yoğurdu, labneh, tuzlu yoğurt, kurut gibi fermente süt ürünleri olarak tanımlanır (Türk Gıda Kodeksi-Fermente Süt Ürünleri Tebliği 2009). Türk Gıda Kodeksi'nde bahsi geçen ve daha yaygın olarak üretimi yapılan bu ürünlerin yanında kefirin de konsantre edilerek tüketiciler için konsantre fermente ürün yelpazesine yeni bir ürün olarak kazandırılması, ürünün bazı özelliklerinin belirlenmesi önem arz etmektedir.

Gerçekleştirilen bu çalışmada 4 farklı üretim metodu ve 2 farklı kültür ile üretilen konsantre kefirler, $4^{\circ} \mathrm{C}$ 'de 30 gün süre ile depolanmıştır. Sağlık açısından faydaları bilimsel çalışmalarda vurgulanan ve probiyotik mikroorganizmaları ihtiva etmesi nedeniyle de probiyotik bir fermente süt ürünü olan kefir, geleneksel bir içeceğimizdir. Esasen orijini Kafkas bölgesine dayanmaktadır. İsmini, hoş bir tat anlamına gelen Kafkas bölgesine ait bir kelime olan "keyif"ten alan kefirin ilk üretimi, keçi ve inek sütü karışımı ve kefir tanesi kullanılarak yapılmıştır. Ekşi bir tadı olan kefir, az miktarda alkol ve karbondioksit içerir. Endüstriyel üretiminde, kefir tanesi yerine kefir kültürü kullanılır ve endüstriyel kefirin alkol oranı $\% 0.02$ 'dir. Ülkemizde üretimi genellikle kefir tanesi kullanılarak geleneksel yöntemlerle yapılır. Ancak yakın bir tarihten itibaren bazı ticari firmalar kefir kültürü kullanarak endüstriyel kefir üretimi gerçekleştirmektedir. Özellikle kurumsallaşmış büyük firmaların da aralarında bulunduğu bazı üreticiler, endüstriyel olarak kefir üretimine ilgi göstermiş, sade ve meyveli karışımları market raflarında görülmüştür. Bununla beraber kefir satışları hiçbir zaman yoğurt satışları ile boy ölçüşebilecek seviyeye gelmemiştir. Bunun başlica sebepleri, ürünün yeterince tanınmıyor olması ve dolayısıyla günlük beslenme kültürümüze yerleşememesi, özellikle mayalar gibi içerdiği bazı mikroorganizmalardan dolayı raf ömrünün kısa oluşu ve üretim maliyetinin yoğurtla kıyaslandığında düşük olmasına rağmen satış fiyatının yüksekliği olarak özetlenebilir. Bundan başka diğer önemli bir konu da, probiyotik olduğu iddia edilen çoğu ürünün, raf ömrü tamamlanmadan bile, probiyotik ürünler için şart koşulan ve kritik olan, içermesi gereken canlı probiyotik mikroorganizma sayısından daha az sayıda canlı probiyotik mikroorganizma ihtiva etmesidir. Gerçekleştirilen bu çalışma ile, ülkemizin probiyotik ürün yelpazesine farklı tat ve aromaya sahip yeni bir ürün eklenmesi, konsantrasyon işlemi ile ürünlerin ihtiva ettiği probiyotik mikroorganizma sayısının da dolaylı olarak artırılması ve raf ömrü boyunca kritik sayının altına düşmesinin engellenmesi, ürünün raf ömrünün uzatılması ile taşıma ve depolama maliyetlerinin azaltılması amaçlanmaktadır.

\section{Materyal ve Yöntem}

\subsection{Materyal}

Konsantre kefirlerin üretim hammaddesi olan 1 L'lik paketlerde yarım yağlı UHT inek sütleri (Pınar yarım yağlı UHT inek sütü) piyasadan satın alınarak temin edilmiş ve bu sütlerin bazı belirleyici özelliklerine ait analiz sonuçları Çizelge 1 'de verilmiştir. Süt tozu ilavesiyle konsantre kefir üretiminde kullanılan yağsız inek süt tozu piyasadan satın alınarak temin edilmiştir (İzi Süt Gıda Mamulleri Sanayi ve Tic. A.Ş. KONYA). Konsantre kefir üretiminde kullanılan kefir danesi Akdeniz Üniversitesi Mühendislik Fakültesi Gıda Mühendisliği Bölümü Süt Teknolojisi Laboratuvarı'ndan temin edilmiştir. 
Kefir kültürü ise piyasadan satın alınarak temin edilmiştir (Danisco, DANIMARKA).

Çizelge 1. Konsantre kefirlerin üretiminde kullanılan inek sütünün bazı fizikokimyasal özelliklerine ait değerler.

Table 1. Values of some physicochemical properties of cow milk used in the production of concentrated kefir.

\begin{tabular}{ll}
\hline Analizler & İnek Sütü \\
\hline Kuru Madde (\%) & $9.36 \pm 0.09$ \\
Yağ (\%) & $1.50 \pm 0.00$ \\
YSKM* (\%) & $7.86 \pm 0.09$ \\
Protein (\%) & $2.78 \pm 0.00$ \\
Kül (\%) & $0.43 \pm 0.05$ \\
pH & $6.63 \pm 0.00$ \\
Titrasyon Asitliği (\%) & $0.15 \pm 0.04$
\end{tabular}

$\mathrm{X} \pm \mathrm{SD}$ : ortlama \pm standart sapma, YSKM: Yağsız süt kuru maddesi.

\subsection{Metot}

\subsubsection{Konsantre kefir üretimi}

Piyasadan temin edilmiş olan yarım yağlı UHT inek sütleri, üretilen her bir ürün için; üretim yöntemindeki farlılıklara bağlı olarak, farklı miktarlarda ayrılarak üretime hazırlanmıştır. Üretimlerde $0.015 \mathrm{mg} \mathrm{L}^{-1}$ oranında (Ön denemelerde belirlenen oranda) kefir kültürü kullanılmıştır. Ayrıca kefir danesinin kullanılacağı üretimlerde, kefir danelerinin mayalama işleminden sonra konsantre üründen ayrıştırılmasının zor olacağ 1 düşünüldüğünden, kefir danesi ile mayalama işlemi yerine, \%8 oranında (Ön denemelerde belirlenen oranda) kefir süzüntüsü starter kültür olarak kullanılmıştır. Kefir süzüntüsü ise $\% 6$ oranında kefir danesi kullanılarak (Ön denemelerde belirlenen oranda) elde edilmiştir. Bu amaçla süt içerisine $\% 6$ oranında kefir danesi eklenip, $22^{\circ} \mathrm{C}^{\prime}$ de fermente edilmiş ve $\mathrm{pH}$ düzeyi 4.6 olduğunda mayalama işlemi sonlandırılarak kefir süzüntüsü elde edilmiştir (Koroleva ve ark. 1978).

Aşağıdaki başlıklar altında her bir farklı yöntemle üretilen konsantre kefirlerin üretim aşamaları anlatılmıştır.

\subsubsection{Süt tozu ilavesiyle konsantre kefir üretimi}

Süt tozu ilavesiyle konsantre kefir üretiminde kullanılan yarım yağl1 UHT inek sütü $40^{\circ} \mathrm{C}$ 'ye kadar 1sıtılıp, sütün yağsız kuru madde oranı $\% 20 \pm 2$ olacak şekilde yağsız süt tozu ilave edilerek (süt tozunun nem oranı belirlendikten sonra kütle denkliği kurularak hesaplanmıştır) kuru madde düzeyi artırılmıştır. Kuru maddesi artırılan süt, $95^{\circ} \mathrm{C}$ 'de 5 dakika 1 sıl işleme tabi tutulduktan sonra (1s1l işlem süt tozundan kaynaklanabilecek bulaşmaları önlemek için yapılmıştır) $22^{\circ} \mathrm{C}$ 'ye soğutulup iki eşit kısma ayrılarak, kısımlardan birine kefir kültürü, diğerine ise kefir süzüntüsü ayrı ayrı inoküle edilerek aynı sıcaklıklarda inkübe edilmiştir. Daha sonra sütlerin $\mathrm{pH}$ değerleri 4.6-4.7 olunca inkübasyon işlemi sonlandırılarak konsantre kefirler üretilmiştir (Şekil 1).

\subsubsection{Geleneksel süzme yöntemi ile konsantre kefir üretimi}

Yarım yağlı UHT inek sütü iki eşit kısma ayrılıp, kısımlardan biri kefir kültürü, diğeri ise kefir süzüntüsü ile ayrı ayrı aşılanarak $22^{\circ} \mathrm{C}$ 'de fermente edilmiştir. Ürünlerin $\mathrm{pH}$ değerleri 4.6-4.7 olunca inkübasyon işlemi sonlandırılmış ve bu şekilde üretilmiş olan kefirler geleneksel yöntemle süzme işlemi için bez keselere (standart Amerikan pamuklu bez) boşaltılıp $4^{\circ} \mathrm{C}$ 'de kuru madde düzeyleri $\% 20 \pm 2$ oluncaya kadar süzme işlemine devam edilerek konsantre kefirler üretilmiştir (Şekil 1).

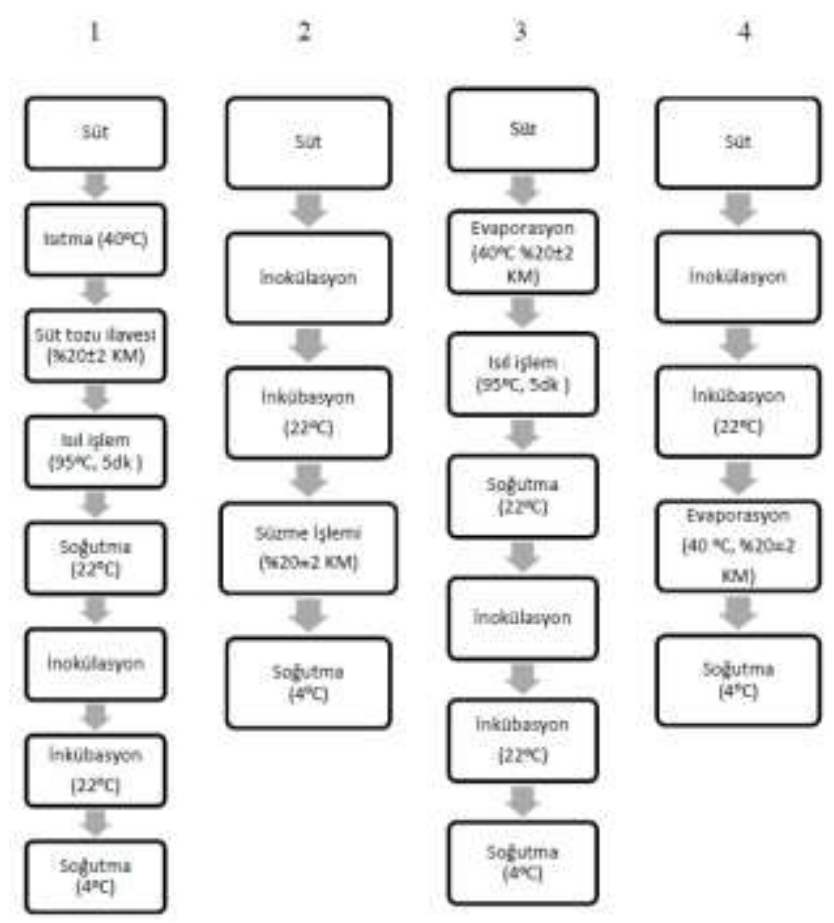

Şekil 1. Süt tozu ilavesiyle konsantre kefir üretimi 1 numaralı akım şemasında, Geleneksel süzme yöntemi ile konsantre kefir üretimi 2 numaralı akım şemasında, Evapore edilerek kuru maddesi artırılan sütlerden konsantre kefir üretimi 3 numaralı akım şemasında ve Üretilen kefirlerin evapore edilmesiyle konsantre kefir üretimi 4 numaralı akım şemasında gösterilmiştir.

Figure 1. Production of concentrated kefir with the addition of milk powder in the flow chart number 1 , Concentrated kefir production with traditional filtration method in flow chart number 2, Production of concentrated kefir from milk with increased dry matter by evaporating in the flow chart number 3 and Concentrated kefir production by evaporating the produced kefir are shown in the flow chart number 4. 


\subsubsection{Evapore edilerek kuru maddesi artırlan sütlerden konsantre kefir üretimi}

Yarım yağlı UHT inek sütü, rotary evaporatörde (HEIDOLPH Laborota 4000 efficient, ALMANYA) $40^{\circ} \mathrm{C}$ sıcaklıkta, ön denemelerde belirlenen $150 \mathrm{rpm}$ devir sayısı ve 60 mbar basınçta, kuru madde oranı $\% 20 \pm 2$ oluncaya kadar evapore edilmiștir. Kuru maddesi artırılan süt, $95^{\circ} \mathrm{C}$ 'de 5 dakika 1sıl işleme tabi tutulduktan sonra $22^{\circ} \mathrm{C}$ 'ye soğutulup iki eşit kısma ayrılmıș, kısımlardan birine kefir kültürü, diğerine ise kefir süzüntüsü inoküle edilerek fermente edilmiştir. $\mathrm{pH}$ değerleri 4.6-4.7 olunca inkübasyon işlemi sonlandırılmış ve konsantre kefirlerin üretimleri sağlanmıştır (Şekil 1).

\subsubsection{4. Üretilen kefirlerin evapore edilmesiyle konsantre kefir üretimi}

Yarım yağlı UHT inek sütü iki eşit kısma ayrılıp, kısımlardan birine kefir kültürü, diğerine ise kefir süzüntüsü ilave edilerek inokülasyon yapılmış ve $22^{\circ} \mathrm{C}$ 'de fermente edilmiştir. Ürünlerin $\mathrm{pH}$ değerleri 4.6-4.7 olunca inkübasyon işlemi sonlandırılmıș ve elde edilen kefirler rotary evaporatörde $40^{\circ} \mathrm{C}$ 'de, ön denemelerde belirlenen $150 \mathrm{rpm}$ devir sayıs1 ve 60 mbar basınçta, kuru madde oranları $\% 20 \pm 2$ oluncaya kadar tutularak konsantre kefirler elde edilmiştir (Şekil 1).

\subsection{2. Örneklerin depolanmast}

Üretimler sonunda elde edilen konsantre kefirlerin kuru madde, protein, yağ ve kül miktarları belirlenmiş, daha sonra örnekler ağzı kapaklı steril plastik kaplara ayrı ayrı konulmuş ve 30 gün süre ile buzdolabı sıcaklığında $\left(4^{\circ} \mathrm{C}\right)$ depolanmıştır. Depolamanın 1., 15. ve 30. günlerinde de her gün için ayrı ayrı olmak üzere, örneklerde titrasyon asitliği, $\mathrm{pH}$, tekstür, su tutma kapasitesi ve mikrobiyojik analizler yapılmıştır.

\subsubsection{Sütlerde yapılan fizikokimyasal analizler}

Örneklerin kuru madde, yağ, protein, kül miktarları Metin (2008)'e, titrasyon asitliği ise Kurt ve ark. (1993)'na göre yapılmıştır. Örneklerin $\mathrm{pH}$ değerleri, $\mathrm{pH}$ metre (Thermo Scientific Orion 2 Star, ABD) kullanılarak belirlenmiştir.

Konsantre kefirlerde sertlik değerleri TA.XT Plus tekstür analiz cihazı (Stable Microsystems, Godalming, Surrey, UK) ile Haque ve ark. (2001)'nın kullandığı yöntem modifiye edilerek tespit edilmiştir. Konsantre kefir örneklerinin sertlik analizi sırasında örnek sıcaklıkları $4^{\circ} \mathrm{C}$ olup, analiz $25 \mathrm{~mm}$ 'lik silindir prob kullanılarak ve test hizı $1 \mathrm{~mm} \mathrm{~s}^{-1}$, trigger kuvveti $5 \mathrm{~kg}$ ve uzaklık $45 \mathrm{~mm}$ olacak şekilde yapılmıştır.

Konsantre kefir örneklerinin su tutma kapasiteleri Remeuf ve ark. (2003)'in bildirdiği yöntem modifiye edilerek belirlenmiştir. Buna göre $25^{\prime} \mathrm{er} \mathrm{g}$ konsantre kefir örnekleri santrifüj tüpleri içerisine tartılıp, $10^{\circ} \mathrm{C}$ 'de $6000 \mathrm{~g}$ 'de 10 dakika süreyle santrifüj (SIGMA-3K30 İNGILTERE) edilmiş, santrifüj sonrası santrifüj tüplerinin üstlerinde kalan serum kısımları döküldükten sonra geriye kalan kısımlar tartılıp (son tartım) su tutması kapasitelerine ait değerler aşağıdaki formül kullanılarak hesaplanmıştır. Su tutma kapasitesi, ürünlerin raf ömrünün belirlenmesi bakımından önemli bir parametredir. Depolama süresince ürünlerde serum ayrılmasının düşük olması gerekmektedir.

Su tutma kapasitesi $(\%)=[($ son tartım-santrifüj tüpünün ağırlı̆̆ 1$) /$ örnek miktarı] $\times 100$

\subsubsection{Konsantre kefirlerde yapılan mikrobiyolojik analizler}

Mikrobiyolojik ekimler yapılmadan önce 1/4 kuvvetinde ringer çözeltisi kullanılarak aseptik şartlar altında, uygun desimal seri dilüsyonlar $\left(10^{-1}, 10^{-2}, 10^{-3}, 10^{-4}, 10^{-5}, 10^{-6}, 10^{-7}\right.$, $10^{-8}, 10^{-9}$ ) hazırlanmıştır (Türk Gıda Kodeksi-Fermente Süt Ürünleri Tebliği 2009). Konsantre kefir örneklerinde canlı laktobasil bakteri sayılarının belirlenmesinde, $\mathrm{pH}$ değeri 6.0'ya ayarlanarak (1 N NaOH ve $\mathrm{HCl}$ kullanılarak) sterilize edilmiş $\left(120^{\circ} \mathrm{C}^{\prime}\right.$ de 15 dakika) De Man, Rogasa and Sharp (MRS, Merck, Darmstadt, ALMANYA) agar besi ortamı kullanılmıştır. Analiz dökme plak kültürel sayım yöntemi ile yapılmış ve inkübasyonlar anaerobik ortamda $24-48$ saat süreyle $30^{\circ} \mathrm{C}$ 'de gerçekleştirilmiştir (Öner ve ark. 2010). Canlı laktokok bakteri sayılarının belirlenmesinde, M17 agar (Merck, Darmstadt, ALMANYA) besi ortam 1 sterilize $\left(120^{\circ} \mathrm{C}\right.$ 'de 15 dakika) edilerek kullanılmış ve inkübasyon $24-48$ saat süreyle $30^{\circ} \mathrm{C}$ 'de gerçekleştirilmiştir (Öner ve ark. 2010). Örneklerde canlı lökonostok bakteri sayılarının belirlenmesinde, Mayeux, Sandine \& Elliker (MSE) agar (10 $\mathrm{g} \mathrm{L}^{-1}$ tripton, $2.5 \mathrm{~g} \mathrm{~L}^{-1}$ jelatin, $5 \mathrm{~g} \mathrm{~L}^{-1}$ maya ekstrakt1, $100 \mathrm{~g} \mathrm{~L}^{-1}$ sakaroz, $5 \mathrm{~g} \mathrm{~L}^{-1}$ glukoz, $1 \mathrm{~g} \mathrm{~L}^{-1}$ sodyum sitrat, $75 \mathrm{mg} \mathrm{L}^{-1}$ sodyum azit ve $15 \mathrm{~g} \mathrm{~L}^{-1}$ agar agar) besi ortamı sterilize $\left(120^{\circ} \mathrm{C}^{\prime}\right.$ de 15 dakika) edilerek kullanılmış ve inkübasyon 96-120 saat süreyle $22^{\circ} \mathrm{C}$ 'de gerçekleştirilmiştir (Garcia ve ark. 2006). Canlı asetik asit bakteri sayılarının belirlenmesinde, Acetobacter Peroxydans Medium (APM, Merck, Darmstadt, ALMANYA) agar besi ortamı sterilize $\left(120^{\circ} \mathrm{C}\right.$ 'de 15 dakika) edilerek kullanılmış, uygun dilüsyonlardan yayma plak yöntemi ile ekimler yapılmış ve petri kutuları aerobik ortamda $30^{\circ} \mathrm{C}$ 'de $3-5$ gün süreyle inkübe edilmiştir (Witthuhn ve ark. 2004). Konsantre kefir örneklerinde canlı maya sayılarının belirlenmesinde ise Yeast Extract Glucose Chloramphenicol (YGC, Merck, Damrstadt, ALMANYA) agar besi ortamı sterilize $\left(120^{\circ} \mathrm{C}\right.$ 'de 15 dakika) edilerek kullanılmıştır. Uygun dilüsyonlardan yayma plak yöntemi ile ekimler yapılmış ve petri kutuları aerobik ortamda $25^{\circ} \mathrm{C}$ de $3-5$ gün süreyle inkübasyona bırakılmıştır (Witthuhn ve ark. 2004).

\subsubsection{Istatistiksel analiz}

Araştırma 2 tekerrürlü yapılmış olup, analizler paralelli olarak gerçekleştirilmiştir. Araştırma sonunda elde edilen sonuçlar varyans analizine tabi tutulmuş ve farklı bulunan değerler Duncan Çoklu Karşılaştırma Testi ile karşılaştırılmıştır (Düzgüneș ve ark. 1987). İstatistiksel analizler, SAS Institute Inc. SAS System 9.0 bilgisayar programı ile yapılmıştır.

\section{Bulgular ve Tartışma}

\subsection{Konsantre kefirlerin fizikokimyasal özellikleri}

Farklı yöntemler uygulanarak üretilen konsantre kefirlerin kuru madde, protein, yağ ve kül miktarlarına ilişkin veriler Çizelge 2'de verilmiştir. Yapılan bu çalışmada bütün ürünlerin kuru madde miktarlarının $\% 20 \pm 2$ 'ye ulaşması hedeflenmiş ve örneklerin kuru madde değerleri \%19.45-21.75 arasında bulunmuş, hedeflenen kuru madde düzeyine yakın değerlerde ürünler elde edilmiştir.

Konsantre kefir örneklerinin protein miktarlarına ait ortalama değerlerin \%5.60-10.86 arasında olduğu tespit edilmiştir. Türk Gıda Kodeksi'nin Fermente Süt Ürünleri Tebliği'ne göre konsantre fermente süt ürünleri için protein miktarının fermantasyondan önce veya sonra en az \%5.6 oranında yükseltilmiş olması gerektiği bildirilmiştir (Türk Gıda 
Kodeksi-Fermente Süt Ürünleri Tebliği 2009). Elde edilen sonuçlara göre konsantre kefir örneklerinde belirlenen değerlerin, tebliğde belirtilen şartı karşıladığı, tebliğ ile uyumlu olduğu görülmektedir.

Üretilen ürünlerin yağ miktarlarına ait ortalama değerlerin $\%$ 0.5-2.55 arasında değiştiği saptanmıştır. Örneklere ait yağ değerlerinin geniş aralıkta değiştiği bu durum; süt tozu ile kuru madde düzeyleri artırılan (yağsız süt tozu kullanılmasından dolayı) sütlerden üretilen konsantre kefir örneklerinin yă oranlarının düşük, geleneksel süzme yöntemi ile üretilen konsantre kefir örneklerinin yă değerlerinin ise yüksek olmasından kaynaklanmaktadır. Süzme yönteminde, ayrılan serum ile birlikte kuru madde kaybı olmakta, ancak yă tamamen konsantre üründe kalmakta, dolayısıyla da orantısal olarak yağ değeri yüksek çıkmaktadır. Akın (1998) tarafından yapılan çalışmada farklı starter kültürler kullanarak inek ve koyun sütlerinden hazırlanan farklı fermente süt ürünleri, ultrafiltrasyon ve geleneksel yöntemlerle konsantre edilmiş ve bu ürünlerin sertlik (konsistens) ve organoleptik özellikleri belirlenmiştir. Ultrafiltrasyon ile konsantre edilerek üretilen Bifiduslu fermente süt, Asidofiluslu fermente süt, Bioyoğurt, Bifiduslu yoğurt ve standart yoğurdun yağ oranları \%9.09-9.90, geleneksel yöntemle konsantre edilerek üretilen Bifiduslu fermente süt, Asidofiluslu fermente süt, Bioyoğurt, Bifiduslu yoğurt ve standart yoğurdun yağ oranları ise \%9.19-9.80 olarak bulunmuştur. Gerçekleştirilen bu çalışmada ise üretilen konsantre kefirlerin yağ miktarlarına (\%) ait değerlerin, araştırmacının bildirdiği yağ miktarlarına (\%) ilişkin değerlerden daha düşük olduğu görülmektedir. Söz konusu değerler arasındaki fark, konsantre kefir üretimlerinde kullanılan sütlerin yarım yağlı inek sütü olmasından kaynaklanmaktadır. Ayrıca, uygulanan konsantre etme yöntemine bağlı olarak yağ oranlarının farklılık göstermesi, örneklerin kuru madde bileşiminin içerik olarak farklılık göstermesinden kaynaklanmaktadır. Süzme yönteminde, uzaklaştırılan serum ile birlikte yağsız kuru madde de ayrılmakta, oysa diğer konsantre etme yöntemlerinde yağsız kuru madde kaybı olmamaktadır.

Konsantre kefir örneklerinin kül miktarlarına ait değerlerin \%0.71-1.56 arasında değiştiği saptanmıştır. Yazıcı ve Akgün (2004) tarafindan, protein esaslı yağ yerine geçen katk1 maddeleri farklı oranlarda kullanılarak, farklı yağ oranlarına sahip ve süzme yöntemiyle konsantre yoğurtlar üretilmiştir. Depolama süresince, kül değerlerinin $\% 0.5$ ve $\% 2$ yağ oranına sahip katkı maddesiz yoğurtlar için \%0.65-0.73 arasında değiştiği tespit edilmiş̧ir.

Konsantre kefir örneklerinin ortalama $\mathrm{pH}$ değerlerinin Duncan Çoklu Karşılaştırma Testi sonuçları Çizelge 3'de verilmiştir. Çizelge incelendiğinde, kültür çeşidinin konsantre kefir örneklerinin $\mathrm{pH}$ değerlerinde farklılığa neden olduğu ve bu farklılığın istatistiksel olarak $(P<0.05)$ önemli olduğu görülmektedir. Ayrıca farklı konsantre etme yöntemleriyle

Çizelge 2. Konsantre kefir örneklerinin fizikokimyasal bazı özelliklerine ait değerler.

Table 2. Values of some physicochemical properties of concentrated kefir samples.

\begin{tabular}{cccc}
\hline Örnek & Kuru madde $(\%)$ & Protein $(\%)$ & Yağ $(\%)$ \\
\hline KK1 & $19.78 \pm 0.01$ & $6.61 \pm 0.26$ & $0.60 \pm 0.10$ \\
KT1 & $19.45 \pm 0.13$ & $5.60 \pm 0.22$ & $0.50 \pm 0.00$ \\
KK2 & $20.27 \pm 0.20$ & $9.04 \pm 0.64$ & $2.55 \pm 0.05$ \\
KT2 & $21.75 \pm 0.08$ & $10.86 \pm 0.76$ & $2.45 \pm 0.05$ \\
KK3 & $19.83 \pm 0.22$ & $7.12 \pm 0.08$ & $1.60 \pm 0.00$ \\
KT3 & $19.50 \pm 0.09$ & $7.25 \pm 0.09$ & $1.55 \pm 0.05$ \\
KK4 & $20.08 \pm 0.02$ & $6.53 \pm 0.05$ & $1.40 \pm 0.10$ \\
KT4 & $20.68 \pm 0.04$ & $7.33 \pm 0.44$ & $1.020 .71 \pm 0.08$ \\
\hline
\end{tabular}

$\mathrm{X} \pm$ SD: ortlama \pm standart sapma, KK1: Starter kültür kullanılarak, süt tozu ilavesiyle üretilen konsantre kefir örnekleri, KT1: Kefir süzüntüsü kullanılarak, süt tozu ilavesiyle üretilen konsantre kefir örnekleri, KK2: Starter kültür kullanılarak, süzme yöntemiyle üretilen konsantre kefir örnekleri, KT2: Kefir süzüntüsü kullanılarak, süzme yöntemiyle üretilen konsantre kefir örnekleri, KK3: Starter kültür kullanılarak, sütün evapore edilmesiyle üretilen konsantre kefir örnekleri, KT3: Kefir süzüntüsü kullanılarak, sütün evapore edilmesiyle üretilen konsantre kefir örnekleri, KT4: Starter kültür kullanılarak, elde edilen kefirlerin evapore edilmesiyle üretilen konsantre kefir örnekleri, KT3: Kefir süzüntüsü kullanılarak, elde edilen kefirlerin evapore edilmesiyle üretilen konsantre kefir örnekleri.

Çizelge 3. Konsantre kefir örneklerinin pH, titrasyon asitliği ve su tutma kapasitesi değerlerinin ortalamalarına ait Duncan çoklu karşılaştırma testi sonuçları.

Table 3. Duncan multiple comparison test results for the averages of $\mathrm{pH}$, titration acidity and water retention capacity values of concentrated kefir samples.

\begin{tabular}{|c|c|c|c|}
\hline Uygulamalar & $\mathrm{pH}$ & Titrasyon asitliği (\%) & Su tutma kapasitesi (\%) \\
\hline \multicolumn{4}{|l|}{ Kültür Çeşidi } \\
\hline Starter Kültür & $4.620 \pm 0.022^{\mathrm{a}}$ & $1.428 \pm 0.023^{\mathrm{b}}$ & $67.668 \pm 2.414^{\mathrm{a}}$ \\
\hline Kefir Danesi & $4.405 \pm 0.031^{\mathrm{b}}$ & $1.690 \pm 0.058^{\mathrm{a}}$ & $65.549 \pm 1.726^{\mathrm{b}}$ \\
\hline \multicolumn{4}{|l|}{ Konsantre Etme Yöntemi } \\
\hline Sütlere Süt Tozu İlavesi & $4.579 \pm 0.054^{\mathrm{b}}$ & $1.538 \pm 0.053^{\mathrm{b}}$ & $57.536 \pm 0.706^{\mathrm{d}}$ \\
\hline Üretilen Kefirlerin Süzülmesi & $4.454 \pm 0.027^{\mathrm{c}}$ & $1.437 \pm 0.041^{\mathrm{c}}$ & $82.909 \pm 1.186^{\mathrm{a}}$ \\
\hline Sütlerin Evapore Edilmesi & $4.632 \pm 0.033^{\mathrm{a}}$ & $1.458 \pm 0.047^{\mathrm{c}}$ & $62.318 \pm 0.624^{\mathrm{c}}$ \\
\hline Üretilen Kefirlerin Evapore Edilmesi & $4.385 \pm 0.046^{\mathrm{d}}$ & $1.823 \pm 0.083^{\mathrm{a}}$ & $63.672 \pm 0.935^{\mathrm{b}}$ \\
\hline \multicolumn{4}{|l|}{ Depolama Süresi } \\
\hline 1. gün & $4.542 \pm 0.043^{\mathrm{a}}$ & $1.528 \pm 0.070^{\mathrm{b}}$ & $65.805 \pm 2.825^{\mathrm{b}}$ \\
\hline 15. gün & $4.499 \pm 0.046^{\mathrm{b}}$ & $1.549 \pm 0.061^{\mathrm{b}}$ & $67.278 \pm 2.513^{\mathrm{a}}$ \\
\hline 30. gün & $4.497 \pm 0.024^{\mathrm{b}}$ & $1.615 \pm 0.057^{\mathrm{a}}$ & $66.743 \pm 2.473^{\mathrm{a}}$ \\
\hline
\end{tabular}


üretilen konsantre kefir örneklerinin $\mathrm{pH}$ değerlerinin istatistiksel olarak farklılık gösterdiği, üretilen kefirlerin evapore edilmesi yöntemiyle elde edilen konsantre kefir örneklerinin $\mathrm{pH}$ değerlerinin daha düşük düzeyde $(P<0.05)$ olduğu tespit edilmiştir. $\mathrm{Bu}$ durum, fermentasyon esnasında meydana gelen laktik asitin üründe orantısal olarak miktarının artmasından kaynaklanmaktadır. Diğer üretim yöntemlerinde laktik asit üründe konsantre olmamaktadır. Süzme yönteminde serum ile birlikte uzaklaşmakta, süt tozu katılarak ve evapore edilerek konsantre edilen sütlerden üretilen konsantre kefirlerde ise fermentasyon sonlandırıldıktan sonra laktik asitin üründe konsantre olmasına zemin hazırlayacak bir işlem bulunmamaktadır. Bununla birlikte, depolama süresince tüm örneklerin $\mathrm{pH}$ değerlerinde azalma $(P<0.05)$ gözlenmiştir. Yapılan bir çalışmada ultrafiltrasyonla konsantre edilen Bifiduslu fermente süt, Asidofiluslu fermente süt, Bioyoğurt, Bifiduslu yoğurt ve standart yoğurdun $\mathrm{pH}$ değerlerinin 4.11-4.63, geleneksel yöntemle konsantre edilenlerin $\mathrm{pH}$ değerlerinin ise 4.00-4.64 arasında değiştiği bildirilmiştir (Akın 1998).

Elde edilen örneklerin titrasyon asitliğine ait ortalama değerlerin Duncan Çoklu Karşılaştırma Testi sonuçları Çizelge 3'de verilmiştir. Çizelge incelendiğinde kullanılan kültür çeşidinin konsantre kefir örneklerine ait titrasyon asitliği değerleri üzerinde farklılık meydana getirdiği ve bu farkın istatistiksel olarak önemli $(P<0.05)$ olduğu belirlenmiştir. Konsantre etme yönteminin titrasyon asitliği üzerine etkisi incelendiğinde ise üretilen kefirlerin süzülmesi ve sütlerin evapore edilmesi yöntemleri uygulanarak üretilen konsantre kefir örneklerine ait titrasyon asitliği değerlerinin benzerlik gösterdiği anlaşılmaktadır. Ayrıca depolama süresince örneklere ait titrasyon asitliği değerlerinin arttığı ve söz konusu artışın istatistiksel olarak önemli $(P<0.05)$ olduğu tespit edilmiştir.

Konsantre kefir örneklerinin su tutma kapasitesine ait ortalama değerlerin Duncan Çoklu Karşılaştırma Testi sonuçları Çizelge 3'de verilmiştir. Çizelge incelendiğinde, kullanılan kültür çeşidinin konsantre kefirlerin su tutma kapasitesine ait değerleri üzerinde farklılığa neden olduğu ve bu farkın istatistiksel olarak $(P<0.05)$ önemli olduğu görülmektedir. $\mathrm{Bu}$ durumun kullanılan kültür içerisindeki mikroorganizmaların ekzopolisakkarit üretimlerinin farklılığından kaynaklanabileceği düşünülmektedir. Ayrıca uygulanan konsantre etme yöntemine bağlı olarak da, konsantre kefir örneklerinin su tutma kapasitesi değerleri arasında önemli bir farklılık $(P<0.05)$ olduğu görülmektedir. Üretilen kefirlerin süzülmesi ile elde edilen konsantre kefir örneklerinin su tutma kapasitesine ait ortalama değerlerin, diğer konsantre etme yöntemleri uygulanarak üretilen örneklere ait değerlere göre daha yüksek olduğu saptanmıştır. Üretilen kefirlerin süzülmesi ile elde edilen konsantre kefir örneklerinde, yöntem gereği zaten serum uzaklaştırılması söz konusudur. Dolayısıyla serum uzaklaştırılmıştır ve bu nedenle de bu yöntem ile üretilen örneklerin su tutma kapasitesine ait değerlerinin yüksek olması beklenen bir durum olarak değerlendirilmektedir. Depolama süresince konsantre kefir örneklerinin su tutma kapasitesine ait değerler arasında istatistiksel bir farklılık $(P<0.05)$ olduğu, depolamanın birinci gününde elde edilen su tutma kapasitesi değerlerinin daha düşük olduğu bulunmuştur. Mousa ve ark. (2014) tarafindan, Bifidobacterium bifidum F-35 suşunun enkapsule edilerek (tek tabakalı serum protein enkapsülasyonu, çift tabakalı sodyum aljinat kaplı serum proteini enkapsülasyonu) veya serbest hücre formunda inoküle edilmesiyle üretilen set yoğurtların fizikokimyasal, tekstürel, mikrobiyolojik ve duyusal olarak değerlendirilmesinin yapıldı̆̆ çalışmalarında, kuru madde miktarları \%13.39-14.27 arasında değişen yoğurtların su tutma oranlarının 14 günlük depolama süresince \%54.67-60.80 arasında değiştiği saptanmıştır. Çalışmanın sonuçları, yapılan bu çalışmanın sonuçları ile uyum göstermektedir.

Konsantre kefir örneklerinin sertlik değerlerinin ortalamalarına ait Duncan karşılaştırma testi sonuçları Çizelge 4'de verilmiştir. Kullanılan kültür çeşidinin, konsantre kefirlerin sertlik değerlerinde farklılığa neden olduğu ve bu farklılığın istatistiksel olarak $(P<0.05)$ önemli olduğu görülmüştür. $\mathrm{Bu}$ durumun kullanılan kültür içerisindeki mikroorganizmaların ekzopolisakkarit üretimlerinin farklılı̆̆ından kaynaklanabileceği düşünülmektedir. Ayrıca üretilen kefirlerin süzülmesi ile elde edilen konsantre kefir örneklerinin sertlik değerlerinin, diğer yöntemlerle üretilen örneklerin sertlik değerlerinden farklı olduğu ve bu farklılığın istatistiksel olarak önemli $(P<0.05)$ olduğu anlaşılmaktadır. Üretilen kefirlerin süzülmesi ile elde edilen konsantre kefir örneklerinin sertlik değerlerinin, diğer konsantre etme yöntemleri uygulanarak üretilen örneklere ait ortalama değerlere göre daha yüksek olduğu saptanmıştır. Üretilen kefirlerin süzülmesi ile elde edilen konsantre kefir örneklerinde, yöntem gereği serum uzaklaştırılması söz konusudur. Dolayısıyla serum ile birlikte suda çözünür kuru madde de uzaklaşmaktadır. Elde edilen konsantre üründe suda çözünür kuru madde miktarı azalmıştır. Bu durumun örneklerin sertlik değerlerinin yüksek olmasına sebep olduğu düşünülmektedir. Bundan başka, depolama süresince örneklere ait sertlik değerlerinin arttı̆̆ 1 ve bu artışın istatistiksel olarak önemli $(P<0.05)$ olduğu belirlenmiştir. Bu durumun, depolama süresince ürün içerisinde yeni bağların oluşmasından kaynaklanabileceği düşünülmektedir. Sarıca (2013) tarafından yapılan çalışmada, inek, keçi ve inek-keçi sütü karışımından farklı yöntemlerle üretilen konsantre Asidofiluslu süt örneklerinin fizikokimyasal, mikrobiyolojik ve duyusal özellikleri araştırılmış, inek sütü ile üretilen örneklerin sertlik değerlerinin depolamanın 1. günü 17.25-125.22 g, 15. günü 24.20-175.98 g ve 30. günü 27.43-211.33 g arasında değiştiği saptanmıştır. Ayrıca süzme yöntemiyle üretilen konsantre Asidofiluslu süt örneklerine ait sertlik değerlerinin diğer yöntemlerle üretilen örneklere ait değerlerden daha yüksek olduğu tespit edilmiştir. Bundan başka sertlik değerlerinin depolama süresince artış gösterdiği bulunmuştur. Sonuç olarak gerçekleştirilen bu çalışmada da konsantre kefir örneklerinin sertlik değerleri depolama süresince artış göstermiş ve üretilen kefirlerin süzülmesi ile elde edilen konsantre örneklerin sertlik değerlerinin diğer konsantre etme yöntemleriyle üretilen örneklere ait değerlere göre daha yüksek olduğu tespit edilmiştir.

\subsection{Konsantre kefirlerin mikrobiyolojik analiz sonuçları}

Konsantre kefir örneklerinin laktobasil, laktokok, lökonostok, asetik asit bakterileri ve maya sayılarının $\left(\log -k_{0 b} \mathrm{~g}^{-1}\right)$ ortalamalarına ait Duncan çoklu karşılaştırma testi sonuçları Çizelge 5'de verilmiştir.

Konsantre kefir örneklerinin laktobasil sayısına ait ortalama değerlerin Duncan Çoklu Karşılaştırma Testi sonuçları incelendiğinde, kullanılan kültür çeşidinin, konsantre kefir örneklerinin laktobasil sayısına ait değerleri üzerinde farklılığa neden olduğu ve bu farklılığın istatistiksel olarak $(P<0.05)$ önemli olduğu görülmektedir. Buna karşın, üretimlerde uygulanan konsantre etme yöntemine bağlı olarak konsantre kefir örneklerinin, laktobasil sayısına ait değerlerinde istatistiksel olarak farkl11ı $(P>0.05)$ tespit edilmemiştir. 
Çizelge 4. Konsantre kefir örneklerinin sertlik değerlerinin ortalamalarına ait Duncan çoklu karşılaştırma testi sonuçları.

Table 4. Duncan multiple comparison test results for the average of hardness values of concentrated kefir samples.

\begin{tabular}{lc}
\hline Uygulamalar & Sertlik \\
\hline Kültür Çeşidi & $71.95 \pm 15.60^{\mathrm{a}}$ \\
\hline Starter Kültür & $54.03 \pm 11.68^{\mathrm{b}}$ \\
\hline Kefir Danesi & $27.18 \pm 1.67^{\mathrm{b}}$ \\
\hline Konsantre Etme Yöntemi & $165.78 \pm 17.88^{\mathrm{a}}$ \\
\hline Sütlere Süt Tozu İlavesi & $30.61 \pm 3.31^{\mathrm{b}}$ \\
Üretilen Kefirlerin Süzülmesi & $28.39 \pm 1.57^{\mathrm{b}}$ \\
Sütlerin Evapore Edilmesi & \\
Üretilen Kefirlerin Evapore Edilmesi & $43.85 \pm 9.55^{\mathrm{c}}$ \\
\hline Depolama Süresi & $62.29 \pm 16.45^{\mathrm{b}}$ \\
\hline 1. gün & $82.82 \pm 21.84^{\mathrm{a}}$ \\
15. gün & \\
30. gün &
\end{tabular}

Çizelge 5. Konsantre kefir örneklerinin laktobasil, laktokok, lökonostok, asetik asit bakterileri ve maya sayılarının (log-kob g $\left.{ }^{-1}\right)$ ortalamalarına ait Duncan çoklu karşılaştırma testi sonuçları.

Table 5. Duncan multiple comparison test results for the averages of lactobacillus, lactococcus, leukonostoc, acetic acid bacteria and yeast numbers $\left(\log -\right.$ kob g $\left.^{-1}\right)$ of concentrated kefir samples.

\begin{tabular}{|c|c|c|c|c|c|}
\hline Uygulamalar & Laktobasil & Laktokok & Lökonostok & Maya & Asetik asit \\
\hline \multicolumn{6}{|l|}{ Kültür Çeşidi } \\
\hline Starter Kültür & $8.38 \pm 0.14^{b}$ & $8.52 \pm 0.089^{\mathrm{a}}$ & $7.83 \pm 0.11^{\mathrm{a}}$ & $7.76 \pm 0.13^{\mathrm{a}}$ & $8.65 \pm 0.84^{b}$ \\
\hline Kefir Danesi & $8.76 \pm 0.09^{\mathrm{a}}$ & $8.26 \pm 0.168^{\mathrm{b}}$ & $8.06 \pm 0.10^{\mathrm{a}}$ & $7.53 \pm 0.10^{\mathrm{b}}$ & $8.56 \pm 0.89^{\mathrm{a}}$ \\
\hline \multicolumn{6}{|l|}{ Konsantre Etme Yöntemi } \\
\hline Sütlere Süt Tozu İlavesi & $8.46 \pm 0.17^{\mathrm{a}}$ & $8.64 \pm 0.122^{b}$ & $7.67 \pm 0.12^{\mathrm{c}}$ & $7.21 \pm 0.05^{\mathrm{c}}$ & $8.42 \pm 0.13^{\mathrm{c}}$ \\
\hline Üretilen Kefirlerin Süzülmesi & $8.66 \pm 0.25^{\mathrm{a}}$ & $8.91 \pm 0.11^{\mathrm{a}}$ & $8.07 \pm 0.17^{\mathrm{a}, \mathrm{b}}$ & $8.03 \pm 0.14^{\mathrm{b}}$ & $8.74 \pm 0.25^{\mathrm{a}}$ \\
\hline Sütlerin Evapore Edilmesi & $8.60 \pm 0.15^{\mathrm{a}}$ & $8.41 \pm 0.15^{\mathrm{b}}$ & $7.81 \pm 0.14^{\mathrm{c}, \mathrm{b}}$ & $7.15 \pm 0.06^{\mathrm{c}}$ & $8.77 \pm 0.10^{\mathrm{a}}$ \\
\hline Üretilen Kefirlerin Evapore Edilmesi & $8.56 \pm 0.08^{\mathrm{a}}$ & $7.59 \pm 0.21^{\mathrm{c}}$ & $8.23 \pm 0.12^{\mathrm{a}}$ & $8.20 \pm 0.11^{\mathrm{a}}$ & $8.48 \pm 0.06^{\mathrm{b}}$ \\
\hline \multicolumn{6}{|l|}{ Depolama Süresi } \\
\hline 1. gün & $9.01 \pm 0.09^{\mathrm{a}}$ & $8.76 \pm 0.18^{\mathrm{a}}$ & $8.31 \pm 0.11^{\mathrm{a}}$ & $7.51 \pm 0.12^{\mathrm{c}}$ & $9.10 \pm 0.12^{\mathrm{a}}$ \\
\hline 15. gün & $8.54 \pm 0.12^{\mathrm{b}}$ & $8.33 \pm 0.16^{\mathrm{b}}$ & $7.91 \pm 0.11^{\mathrm{b}}$ & $7.63 \pm 0.13^{b}$ & $8.49 \pm 0.09^{b}$ \\
\hline 30. gün & $8.17 \pm 0.15^{\mathrm{c}}$ & $8.08 \pm 0.16^{\mathrm{c}}$ & $7.61 \pm 0.10^{b}$ & $7.80 \pm 0.17^{\mathrm{a}}$ & $8.21 \pm 0.07^{\mathrm{c}}$ \\
\hline
\end{tabular}

Aynı sütundaki farklı harfler ortalamaların $P<0.05$ seviyesinde farklı olduğu ifade etmektedir, $\mathrm{X} \pm \mathrm{SD}$ : ortalama \pm standart sapma

Depolama süresince örneklerin laktobasil sayısına ait değerlerin istatistiksel olarak $(P<0.05)$ azalış gösterdiği belirlenmiştir.

Konsantre kefir örneklerinin laktokok sayısına ait ortalama değerlerin Duncan Çoklu Karşılaştırma Testi sonuçları incelendiğinde kültür çeşidinin, konsantre kefir örneklerinin laktokok sayısına ait ortalama değerleri üzerinde farklılık oluşturduğu ve bu farklılığın istatistiksel olarak $(P<0.05)$ önemli bulunduğu görülmektedir. Ayrıca üretimlerde uygulanan farklı konsantre etme yöntemlerinin, konsantre kefir örneklerinin laktokok sayısına ait ortalama değerleri üzerinde istatistiksel olarak farklılığa $(P<0.05)$ neden olduğu, üretilen kefirlerin süzülmesi ile elde edilen konsantre kefir örneklerinin laktokok sayısına ait ortalama değerlerin, diğer yöntemlerle üretilen örneklere ait söz konusu değerlere kıyasla daha yüksek olduğu tespit edilmiştir. Depolama süresince örneklerin laktokok sayısına ait ortalama değerlerde azalma görüldüğü ve bu azalmanın istatistiksel olarak $(P<0.05)$ önemli bulunduğu saptanmıştır.

Konsantre kefir örneklerinin lökonostok sayısına ait ortalama değerlerin Duncan Çoklu Karşılaştırma Testi sonuçlarından anlaşıldığı gibi, kullanılan kültür çeşidi, konsantre kefir örneklerinin lökonostok sayısına ait değerlerinde istatistiksel olarak farklılığa $(P<0.05)$ neden olmamıştır. Fakat farklı konsantre etme yöntemleriyle üretilen konsantre kefir örneklerinde lökonostok sayısına ait ortalama değerlerin istatistiksel olarak farklılık $(P<0.05)$ gösterdiği tespit edilmiştir. Depolama süresince örneklerin lökonostok sayısına ait ortalama değerlerinde düşme $(P<0.05)$ gözlenmiştir.
Konsantre kefir örneklerinin maya sayısına $\left(\log -\mathrm{kob} \mathrm{g}^{-1}\right)$ ait ortalama değerlerin Duncan Çoklu Karşılaştırma Testi sonuçları incelendiğinde, üretimlerde kullanılan kültür çeşidinin konsantre kefir örneklerinin maya sayısına ait ortalama değerlerinde farklılığa neden olduğu ve bu farkın istatistiksel olarak $(P<0.05)$ önemli olduğu görülmektedir. Ayrıca farklı konsantre etme yöntemleriyle üretilen konsantre kefir örneklerinin maya sayısına ait değerlerin istatistiksel olarak farklılık $(P<0.05)$ gösterdiği, üretilen kefirlerin evapore edilmesi yöntemiyle elde edilen konsantre kefir örneklerinin maya sayısına ait değerlerin, diğer yöntemlerle üretilen örneklere ait değerlere kıyasla daha yüksek olduğu tespit edilmiştir. $\mathrm{Bu}$ durumun ortamda laktik asitin orantısal olarak artışından kaynaklanabileceği düşünülmektedir. Asidik ortamda mayaların canlılığını daha iyi koruduğu bilinmektedir. Bundan başka, depolama süresince örneklerin maya sayısına ait değerlerin artış $(P<0.05)$ gösterdiği saptanmıştır.

Konsantre kefir örneklerinin asetik asit bakterileri sayısına ait ortalama değerlerin Duncan Çoklu Karşılaştırma Testi sonuçları incelendiğinde, kültür çeşidinin konsantre kefir örneklerinin asetik asit bakterileri sayısına ait değerlerinde farklılığa neden olduğu ve bu farkın istatistiksel olarak $(P<0.05)$ önemli olduğu görülmektedir. Ayrıca farklı konsantre etme yöntemleriyle üretilen konsantre kefir örneklerinin asetik asit bakterileri sayısına ait değerlerin istatistiksel olarak farklılık $(P<0.05)$ gösterdiği anlaşılmaktadır. Depolama süresince örneklerin asetik asit bakterileri sayısına ait değerlerinde azalma $(P<0.05)$ gözlenmiştir. Witthuhn ve ark. (2004) geleneksel kefir üretiminin farklı aşamalarındaki mikrobiyal popülasyonun 
araştırıldığı çalışmalarında, asetik asit bakterileri sayısının 6.34-8.41 log-kob g ${ }^{-1}$ olarak değiştiğini tespit etmişlerdir. Yapılan bu çalışmada da asetik asit bakterileri sayısına ait değerlerin benzerlik gösterdiği ve depolama süresince 7.62-9.84 $\log -k_{0 b} \mathrm{~g}^{-1}$ arasında değiştiği saptanmıştır.

\section{Sonuç}

Yapılan bu çalışma sonucunda konsantre kefir örneklerine ait titrasyon asitliği ve sertlik değerlerinin depolama süresince artış gösterdiği tespit edilmiştir. Örneklerin $\mathrm{pH}$ değerlerinin ise depolama süresince düştüğü görülmüştür. En yüksek titrasyon asitliği değeri, üretilen kefirlerin evapore edilmesi yöntemiyle, kefir danesi kullanılarak üretilen örneklerde, en düşük titrasyon asitliği değeri ise sütlerin evapore edilmesi yöntemiyle kefir kültürü kullanılarak üretilen ürünlerde gözlenmiştir. Sertlik açısından en yüksek değerleri starter kültür kullanılarak üretilen kefirlerin süzülmesi ile elde edilen konsantre kefir örnekleri depolamanın 30. gününde alırken, en düşük değerleri ise kefir danesi kullanılarak, sütlerin evapore edilmesi yöntemi ile üretilen konsantre kefir örnekleri, depolamanın 1. gününde almıştır. Konsantre kefir örneklerinde yapılan mikrobiyolojik analizlerde, laktobasil, laktokok, lökonostok, asetik asit bakterilerinin sayılarında depolama süresince azalma gözlenirken, maya sayısında artış tespit edilmiştir. Yapılan analiz sonuçlarının değerlendirilmesi sonucunda fizikokimyasal özellikleri açısından en iyi ürünlerin süzme yöntemiyle üretilen ürünler olduğu tespit edilmiştir.

\section{Teşekkür}

$\mathrm{Bu}$ makale Yüksek Lisans tezinden üretilmiş olup, tez çalışmalarını FYL-2015-390 No'lu proje kodu ile destekleyen Akdeniz Üniversitesi, Bilimsel Araştırma Projeleri Koordinasyon Birimi'ne teşekkür ederiz.

\section{Kaynaklar}

Abdelrahman AR, Adel MA, Smetanska I (2010) Fermented milk products. Nova Science Publishers, Inc., New York 15, pp. 16.

Akın N (1998) İnek ve koyun sütünden üretilen bazı konsantre fermente süt ürünlerinin sertliği ve duyusal özellikleri. Journal of Veterinary and Animal Sciences 23: 583-590.

Düzgüneş O, Kesici T, Kavuncu O, Gürbüz F (1987) Araştırma ve deneme metotları (İstatistik II). Ankara Üniversitesi Ziraat Fakültesi Yayınları, No: 1021, Ankara.

Farkye NY, Ur Rehman S (2011) Chandan R. C. (Editör). Kilara A.(Editör). Dairy ingredients for food processing: concentrated fluid milk ingredients. Blackwell Publishing Ltd., USA, pp. 123134 .
Garcia Fontan MC, Martinez S, Franco I, Carbolla J (2006) Microbiological and chemical changes during the manufacture of kefir made from cows' milk, using a commercial starter culture. International Dairy Journal 16: 762-767.

Güzel-Seydim ZB, Kök-Taş T, Greene KA, Seydim AC (2011) Functional properties of kefir. Taylor\&Francis Group, pp. 261.

Haque A, Richardson RK, Morris ER (2001) Effect of fermentation temperature on the rheology of set and stirred yogurt. Food Hydrocolloids 15: 593-602.

Korkut A (2010) III. Süt ve Süt Hayvancılığı Öğrenci Kongresi. 21 Mayıs Aksaray Üniversitesi Meslek Yüksek Okulu, Aksaray.

Koroleva NS, Bavina NA, Rozhkova IV (1978) Changes in the microflora of kefir during storage. International Dairy Congress, E. 844 (En) All-Union Res. Inst. of Dairy Ind. Moscow, pp. 35-40.

Kurt A, Çakmakçı S, Çağlar A (1993) Süt ve mamulleri muayene ve analiz metotları rehberi. Atatürk Üniversitesi Yayınları: Erzurum, s. 238.

Metin M (2008) Süt ve mamülleri analiz yöntemleri. Ege Üniv. Yayınları: 24, İzmir, s. 439.

Mistry VV (2001) Applied dairy microbiology: fermented milks and cream. Marcel Dekker, Inc. Amerika, s. 301.

Mousa A, Liu X, Chen Y, Zhang H, Chen W (2014) Evaluation of physiochemical, textural, microbiological and sensory characteristics in set yogurt reinforced by microencapsulated Bifidobacterium bifidum F-35. International Journal of Food Science and Technology 49: 1673-1679.

Öner Z, Karahan AG, Çakmakçı ML (2010) Effects of different milk types and starter cultures on kefir. Gida 35: 177-182.

Remeuf F, Mohammed S, Sodini I, Tissier JP (2003) Preliminary observations on the effects of milk fortification and heating on microstructure and physical properties of stirred yoghurt. International Dairy Journal 13: 773-782.

Sarıca E (2013) İnek ve keçi sütü kullanılarak, farklı yöntemlerle üretilen konsantre asidofiluslu sütlerin fizikokimyasal, mikrobiyolojik ve duyusal bazı özeliklerinin belirlenmesi. Yüksek Lisans Tezi, Akdeniz Üniversitesi.

Surono SI, Hosono A (2011) Encyclopedia of dairy sciences: Fermented milks. Elsevier Ltd., England, 2: 470-472.

Türk gıda kodeksi-fermente süt ürünleri tebliği (2009). Tebliğ No: 2009/25. T.C. Resmi Gazete 16.02.2009 tarih ve 27143 say1.

Witthuhn RC, Schoeman T, Britz TJ (2004) Characterisation of the microbial population at different stages of kefir production and kefir grain mass cultivation. International Dairy Journal 15: 383389.

Yazıcı F, Akgün A (2004) Effect of some protein based fat replacers on physical, chemical, textural, and sensory properties of strained yoghurt. Journal of Food Engineering 62: 245-254. 